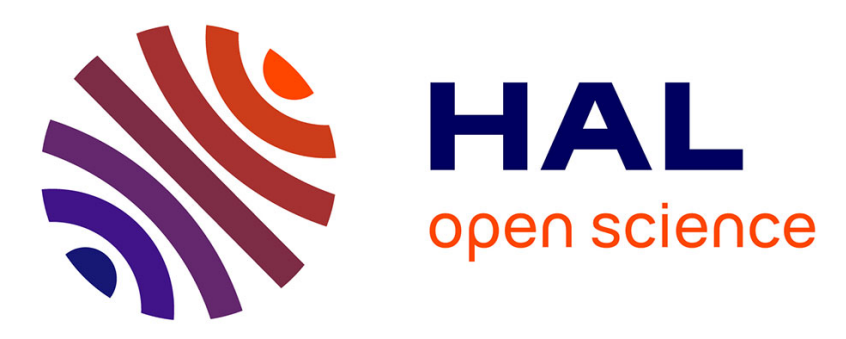

\title{
Post-apartheid ecologies in the City of Cape Town: An examination of plant functional traits in relation to urban gradients
}

Pippin Anderson, Tristan Charles-Dominique, Henrik Ernstson, Erik Andersson, Thomas Elmqvist

\section{To cite this version:}

Pippin Anderson, Tristan Charles-Dominique, Henrik Ernstson, Erik Andersson, Thomas Elmqvist. Post-apartheid ecologies in the City of Cape Town: An examination of plant functional traits in relation to urban gradients. Landscape and Urban Planning, 2020, 193, pp.103662. 10.1016/j.landurbplan.2019.103662 . hal-02414654

\author{
HAL Id: hal-02414654 \\ https://hal.science/hal-02414654
}

Submitted on 18 Nov 2020

HAL is a multi-disciplinary open access archive for the deposit and dissemination of scientific research documents, whether they are published or not. The documents may come from teaching and research institutions in France or abroad, or from public or private research centers.
L'archive ouverte pluridisciplinaire HAL, est destinée au dépôt et à la diffusion de documents scientifiques de niveau recherche, publiés ou non, émanant des établissements d'enseignement et de recherche français ou étrangers, des laboratoires publics ou privés. 


\title{
Post-apartheid ecologies in the City of Cape Town: an examination of plant functional traits in relation to urban gradients
}

\section{Pippin Anderson ${ }^{1}$, Tristan Charles-Dominique ${ }^{2,3}$, Henrik Ernstson ${ }^{4}$, Erik Andersson ${ }^{5}$ and Thomas Elmqvist $^{6}$}

\author{
${ }^{1}$ Department of Environmental and Geographical Science, University of Cape Town, Cape \\ Town, South Africa \\ ${ }^{2}$ Department of Biological Science, University of Cape Town, Cape Town, South Africa \\ ${ }^{3}$ CNRS UMR7618, Sorbonne University, Institute of Ecology and Environmental Sciences Paris, \\ 4, place Jussieu, 75005 Paris, France \\ ${ }^{4}$ African Centre for Cities, University of Cape Town and KTH Environmental Humanities \\ Laboratory \\ ${ }^{5}$ Stockholm Resilience Centre, Stockholm University, Stockholm, Sweden
}




\begin{abstract}
In this study we explore species richness and traits across two urban gradients in the City of Cape Town. The first is the natural-urban boundary and the second is a socio-economic gradient informed by historical race-based apartheid planning. Plant species and cover were recorded in 156 plots sampled from conservation areas, private gardens, and public open green space. The socio-economic gradient transitioned from wealthier, predominantly white neighbourhoods to poorer, predominantly black neighbourhoods. The socio-economic gradient was selected to fall within one original vegetation type to ensure a consistent biophysical template. There is a marked shift between the natural and urban plant communities in the City of Cape Town, with little structural affinity. Urban landscapes are dominated by grass, with low diversity compared to natural counterparts. A significant ecological gradient of reduced biodiversity, traits, and in turn functionality, was found across the socio-economic gradient. Wealthier communities benefit from more private green space, more public green space, and a greater plant diversity. Poorer communities have limited green space on all fronts, and lower plant and trait diversity. Plant communities with limited diversity are less resilient and if exposed to environmental perturbation would lose species, and associated ecosystem services faster than a species rich community. These species-poor plant communities mirror historical apartheid planning that is resistant to change. Recent linkages between biodiversity, functionality, and associated ecosystem services and ecosystem stability, suggests an environmental injustice persists in the City of Cape Town.
\end{abstract}




\section{INTRODUCTION}

The critical factor that sets the ecology of cities apart from their rural counter-parts is the abundance and informing role of people. More than half of the global population live in our cities today and through species filtering, either actively or passively, forge the green spaces of cities. Active filtering is achieved through design, construction, and personal preference and choice, and passive filtering dictated inadvertently through other processes for example the removal of large predators, suppression of natural fire, collapse of pollination webs, or unchecked pollution that results in eutrophication, all of which in turn change local ecologies (Pauw 2007). Social informants of urban ecology such as economics, class and gender, have been studied and recorded, with a wealth of work emerging in recent years (Buchmann 2009, Lubbe et al. 2010, Pickett et al. 2011, Kuruneri-Chitepo and Shackleton 2011, McPhearson et al. 2015). All this plays out on an original ecology evident in the historical vegetation that predates the settlement of the city. Though longer social histories, that pre-date urban settlement, are critically informative in how environments have been used, perceived, and structured in the spaces that cities now occupy, the recent very rapid urbanisation has resulted in dramatic environmental and social impacts (Anderson and O'Farrell 2012). The green spaces of our cities are imperative to the delivery of critical on-site ecosystem services (O'Farrell et al. 2012), account for the nature experienced by the bulk of the global population, inform the well-being of our urban populace (Southon et al. 2018, Fuller et al. 2007, Gross and Lane 2007) and are to be the 'first landscapes' of the majority of the next generation. The importance of urban green spaces cannot be adequately emphasised. As global urban populations grow (Fragkias et al. 2013), so too will the importance of our urban green spaces (Rigolon et al. 2018). This is particularly relevant in the global south where urban expansion is currently most rapid and 
frequently emerges in ways that are different to the well recorded patterns in the global north (Anderson et al. 2013, Seto, Parnell and Elmqvist 2013).

Understanding these urban ecologies, the outcomes of these particular urban filters, and the ensuing ecological functionality, is important but remains elusive. Simple taxonomic biodiversity measures alone fail to capture functioning (Mori et al. 2013), preclude inter-city comparison, where different cities in different regions will have variable taxonomic communities of species (Mori et al. 2013), and impeded the emergence of general theories that could be used to guide urban planning and management (Tomimatsu et al. 2013). Functional traits, those acting and reacting features on which environmental filtering is acting, are suggested as a more mechanistically useful tool for capturing species' response to gradients (Diaz and Cabido 2001, Funk et al. 2017), and acknowledged as important for community stability and functioning (Elmqvist et al. 2003, Flynn et al. 2009, Cardinale et al. 2012, Mori et al. 2013). As operational features functional traits allow the links to be made between species and their performance and role in a community, and can be selected expressly to explore specific drivers, and ecologists tend to use them to analyse and understand the functionality of communities (McDonnell and Hahs 2013). For example, two species may both belong to the Asteraceae family, but one might be a shrub and the other a tree, rendering their contribution to their local ecology completely different. In this paper we make a further contribution from the global south towards understanding the ecology of cities (Rigolon et al. 2018). We analyse how urban management impacts plant species richness and key plant functional traits. We separate urban management, looking at the effects of processes of urbanisation and management at the macro-scale with considerations of conservation areas, public green space and private gardens, from management at micro-scale determined by socio-economic factors at the neighbourhood scale. 
Cape Town provides an important case to understand the influence of macro and micro scale management effects on biodiversity. The city hosts one of the most diverse vegetation types while displaying one of the starkest socio-economically unequal geographies of the world (Mieklejohn and le Roux 2008, Rebelo et al. 2011). Like other areas identified as sites of likely urban expansion (Seto et al. 2013), Cape Town is an identified biodiversity hotspot. The city is situated in the Cape Floristic Region which is the smallest and most diverse of the earth's six floral kingdoms and holds $44 \%$ of the flora of the subcontinent, some 9,000 plant species, in just $90,000 \mathrm{~km}^{2}$ (Rebelo et al. 2006). The city has a further distinction in that it has a persistent racial spatial geography that emerged through apartheid planning where different racial groups were given designated areas in which to reside, with privileged white people allocated neighbourhoods that received excellent municipal services and had easy access to the city centre while black and coloured people were relegated to further flung neighbourhoods with limited municipal infrastructure and services. The current market-based allocation of housing has done little to transform racially, and socio-economically distinct neighbourhoods (Turok 2001). The apartheid legacy is evident in developmental, educational and wealth discrepancies (Turok 2001). The city is characterized by urban sprawl and the stark contrast of middle- to upper-income areas of freestanding houses on large plots adjacent to extensive and rapidly expanding informal settlements; a socio-economic gradient that principally follows racial lines with black and coloured communities living in poor neighbourhoods and informal settlements and white communities living in wealthy neighbourhoods (Goodness and Anderson 2013). We acknowledge the distasteful nature of racial terminology but use it as part of our exploration of persistent racial inequalities. We examine this socio-economic gradient as a 'gradient of perturbation' (Tomimatsu et al. 2013) to develop insights into post-apartheid ecologies in South 
African cities but also with recognition of the potential for inter-city comparisons where globally there is a trend for splintering and increased social incoherence (Graham and Marvin 2001).

With respect to basic species richness and select traits, we set out to address the following questions.

1. How does urbanization affect the vegetation and the ecosystem functions it provides?

2. What are the consequences of socio-economic inequalities on the urban vegetation?

\section{METHODS}

\subsection{Study site}

The City of Cape Town is South Africa's most southwestern city. The city is situated on a Peninsula with an extensive coastline of $307 \mathrm{~km}$, and an interior of both mountainous terrain with Table Mountain rising to just over $1000 \mathrm{~m}$ at the heart of the city, and adjacent flat lands of extensive dune fields known as the Cape Flats. The region experiences a typical Mediterraneanclimate of hot, dry summers and wet winters. The original vegetation of the city is dominated by Fynbos and renosterveld, low, shrubby and fire-prone vegetation types (Rebelo et al. 2006). The city hosts 19 of 440 National Vegetation Types, and of 21 nationally recognized critically endangered vegetation types, 11, are found in the city (Rebelo et al. 2011). Estimates place the number of indigenous plant species in the city at approximately 3350 , of which 190 , that is over 5\%, are endemic to the city itself (Rebelo et al. 2011). Cape Town has a population of approximately 3.7 million, $64 \%$ of the population of Western Cape Province, in just over a million households (Allsopp et al. 2014). The city has an annual growth rate of $3.2 \%$, slightly higher than the national average (Mieklejohn and le Roux 2008). The city has a sprawling 
footprint of $2460 \mathrm{~km}^{2}$ and development ranges from formal housing on large plots set close to Table Mountain to formal and informal housing in very dense settlements out on the low-lying areas called the Cape Flats. Poverty is characteristic of Cape Town, with the percentage employed people between 15 - 64 years at only 50\% (Allsopp et al. 2014) and as much as $35.7 \%$ of households live below the poverty line with less than R 3500 per month (Goodness and Anderson 2013). The city's population has a high burden of disease, in particular of HIV and tuberculosis. Education levels, while better than other areas in the country, are generally low in Cape Town with only $30 \%$ of the population finishing high school at the highest level (Allsopp et al. 2014).

This current study was carried out across two gradients. The first was a rural-to-urban gradient with conservation areas in the city serving as proxies for an original natural state and urban in this case to mean suburban settlement within the city boundary, and the second was across a socio-economic gradient across a subset of neighbourhoods within the broader city. The gradients were selected to lie within what was originally one vegetation type, namely Cape Flats Sand Fynbos. Cape Flats Sand Fynbos is a dense, moderately tall, ericoid shrubland with some taller shrubs (Rebelo et al. 2006). Typical of fynbos, Proteoid and Restioid species are prevalent, with more Asteraceous and Ericaceous species occurring in drier and wetter areas respectively. According to Rebelo et al. (2006), approximately 108 threatened and near threatened Red List species occur on the remnants of this vegetation type. This vegetation is edaphically and climatically constrained and grows on typically acid soils that are relatively deep and tertiary in origin. Three conservation areas were sampled as representative of the natural end of naturalurban gradient. The three conservation areas were Tokai Park, Edith Stephens Reserve, and the Kenilworth Racecourse. The socio-economic gradient runs roughly in a west-east direction from 
the foothills of Table Mountain in the salubrious neighbourhoods of Constantia and Tokai with vineyards and large estate-sized single dwellings, to garden-city planned Bergvliet, to more middle- and lower-income neighbourhoods of Retreat and Grassy Park, and finally to the very poor informal settlement of Vrygrond (Figure 1, Table1). Finding sites with vegetative cover in private gardens in informal settlements proved difficult and as a result a few gardens from the adjacent settlement of Skaapkraal, which sits just south of this transect, were included. Gardens here were taken as small patches of tended land in the immediate proximity of a home. These gardens are not fenced or demarcated as they are in typical suburbia. This gradient runs from wealthier and predominantly white neighbourhoods in the west, through middle-class to lowincome neighbourhoods with the progression east (Table 1), to the poorest neighbourhoods being the informal settlements. Socio-economic data was collected off the Statistics South Africa (STATSA 2011) site.

\section{[Figure 1]}

[Table 1]

\subsection{Gradient sampling}

A total of 156 circular plots, $5 \mathrm{~m}^{2}$ in area, were sampled across the two gradients in question. Plot size was determined as a function of the smaller yards where no more than $5 \mathrm{~m}^{2}$ could be accommodated. Plots were placed randomly using a grid and random number selection approach over a predominantly vegetated site (hard surfaces of brick, or cement were excluded) within each garden, public green space, or conservation site. Within each plot, species presence, cover contribution, and total cover, were recorded. Funk et al. (2008) note the challenge in selecting plant traits where relevance and measurability must both be taken into consideration. In our 
study plant traits were selected to incorporate common life history characteristics and a suite of traits hypothesised to summarize the major changes of functioning due to urban pressure (included were life history, growth form, leaf type, rooting depth, pollination mechanism, seed dispersal mechanism, leaf area). We felt these presented opportunities to consider both human management as well as ecological aspects. For example, some traits can be linked to ecosystem service delivery, where for instance, urban cooling relates to leaf type and area. Other traits relate to ecological and community functioning such as those linked to pollination and dispersal mechanisms. While it would be good to include any number of traits that might relate to urban considerations, trait selection was also constrained by what was available in the databases and published literature, which for a very parochial vegetation type proved a limiting factor where often only the most basic information was available. Plant traits were established through a number of sources including the TRY database (Kattge et al. 2011) Efloras (www.eFloras.org), the University of Berkley online herbarium (Jepson Flora project 2016), the USDA Plants database (USDA, NRCS 2016), and PlantzAfrica (South African National Biodiversity Institute 2008).

\subsection{Analysis}

We analysed the emergent traits of the different communities using community weighted mean (CWM) values. The significance of differences was tested using one-way ANOVAs followed by Post-hoc Tukey HSD. In instances where normality conditions were not met, we applied Kruskall-Wallis tests (non-parametric ANOVA) and pairwise Wilcoxon Mann-Whitney tests with a Holm correction (nonparametric post-hoc tests with a correction for multiple testing). 
Socio-economic gradients and soil types could co-vary in Cape Town and then result in nonmeaningful correlations, with for example the wealthiest areas built on the fertile flanks of Table Mountain. We controlled for this confounding effect by using variation partitioning to estimate the unique and joint effects of soil and socio-economic drivers on the distribution of life-forms. Canonical correspondence analysis (CCA) and Partial CCA were used with two partitions and the significance of testable fractions was evaluated using permutation tests (9999 permutations; $\alpha<0.05$; Borcard et al. 2011). For each of these analyses, adjusted R-squares provided unbiased estimates of the variation explained by the fractions (Peres-Neto et al. 2006). A venn diagram is used to illustrate the results of variation partitioning. Lastly, we tested for spatial autocorrelation in the residuals of our model using the correlogram function (computed using Pearson's R; 999 permutations) of the Vegan package in the R software (Borcard et al. 2011; Bivand \& Piras, 2015; Oksanen et al., 2013). We did not detect any significant autocorrelation at any of the geographical distances (all P-value $>0.2$; Holm correction for multiple testing); we therefore did not fit an explicit description of spatial structure into the models.

\section{RESULTS}

\subsection{Species richness, traits and cover}

Across all 156 sites plots (private $n=70$, public $n=70$, conservation $n=16$ ), a total of 189 plant species were recorded. Species richness is significantly higher in the conservation areas when compared to all others (Table 2). Private gardens generally had greater species richness than public open space, and this trend is only reversed in the very lower income neighbourhoods where public open space has greater richness than private gardens. The lowest species richness is 
found in the private gardens of the Vrygrond informal settlement. Trait richness, that is the number of different traits in a community or site, is highest in the conservation sites and akin to those recorded in private gardens of higher income neighbourhoods with the lowest recorded in the private gardens in the informal settlement. Total plant cover is highest in the conservation sites, and lowest in private gardens of the informal settlement. In the case of plant cover the public green spaces fair better than private gardens in some instances (Table 2).

[Table 2]

Poorer and wealthier neighbourhoods both have high proportions of alien, or exotic, plant species. The greatest difference is between conservation areas which have a low contribution of alien plant species and wealthier private gardens which have the highest contribution. (Figure 2).

[Figure 2]

\subsection{Growth forms}

Community functioning tends to be informed by those plants that dominate cover (Flynn et al. 2009, Cardinale et al. 2012). Consideration of dominant traits associated with growth forms allows scrutiny of the bundle of traits associated with growth forms dominating cover (Figure 3).

\section{[Figure 3]}

We observed a shift between conservation sites dominated by shrubby growth forms, to adjacent urban spaces dominated by grass (Figure 4). Public and private green spaces, while relatively similar when compared to the conservation areas, differ in their abundance of grass cover which 
is higher in public green space, while private gardens have more trees and more herbaceous species.

[Figure 4]

Growth form richness, that is the number of growth forms, across the socio-economic gradient tends to be similar with a slight increase in grass as one moves down the economic gradient with greater grass cover in the lower income neighbourhoods of Grassy Park and Retreat. The exception is the informal settlement of Vrygrond where there is an increase in tree cover, and an increase in succulent cover, and the complete absence of geophytes (Figure 5).

[Figure 5]

Conservation areas in Cape Town have a higher proportion of species that reward animals through their pollination and seed dispersal strategies (Figure 6; Tab.S2).

[Figure 6]

An examination of the relative role of geographic area versus soil, confirm the dominant role of socio-economic factors on species distribution (Figure 7).

[Figure 7]

\section{DISCUSSION}

\subsection{Natural- urban shifts and landscape disconnects at the city scale}


Cities tend serve to increase local biodiversity with the introduction of exotic alien species (Hahs et al. 2009). This is not so for the City of Cape Town where species richness declines with urbanisation. Important to note here is the binary rural versus urban used in exploring urbanisation, where no gradient of urbanisation per se is explored, but rather rural (in the form of conservation areas) is contrasted to urban (in this case suburban cover within the city boundary). Given the significant indigenous plant diversity of the Cape (Rebelo et al. 2011), it is to be expected that the conservation areas in this study are home to greater species richness than adjacent public and private green space. In addition, vegetative cover is generally higher in these natural conservation areas, and they also have the most even spread of growth form diversity. The change across the natural-urban boundary sees a move from a shrub dominated, but structurally diverse community, to one dominated by grass with the inclusion of more trees. The relevance of structural diversity as an informant of the diversity of other taxa is known from other studies (Smith et al. 2005, Gonzalez-Garcia et al. 2009). The structural shift demonstrated here is stark and akin to a biome-level shift likely to manifest in two adjacent systems that function differently and separately.

There is an argument for an ecology in cities where gardens, public parks and conservation areas come together to form something of a mosaic, a complex matrix of 'green' which presents a level of ecological connectivity and functioning (Borgstrom et al. 2013). While this is held as something of a universal truth, work which expressly interrogates connectivity suggests the level of ecological connectivity and functioning to be scale, taxa and management dependent (Goddard et al. 2010). The role of human management as a driver in selecting the flora of our cities is evident in the near complete loss of animal-related traits from our urban flora. A switch to self and wind pollination and dispersal in the urban is well recorded (Pauw 2007, Knapp 
2012). While zoochory is somewhat evident in private gardens, this is likely a function of a selection for aesthetically appealing flowering species (Goodness et al. 2016). This supports Faeth et al. (2011) who note people as the dominant selective force, with the emerging biological community determined by this first-cut plant 'template'. Social informants emerge as critical primary selective forces in cities (Faeth et al. 2011). The ability to purchase plants from nurseries renders the need to produce and disperse seed obsolete (Thompson and McCarthy 2008). What is evident is that the urban matrix of 'green' does not present a contiguous ecological entity, where in this instance private gardens and public space offer limited opportunities to many pollinating and seed dispersing animal species and as such become large spaces of disconnect rather than stepping stones in a broader matrix.

The dominance of lawns in suburban and middle-class areas is well interrogated and relates to social choices around space, sight lines and safety (Larson et al. 2009), and structured by market and cultural-ideological factors (Robbins and Sharp 2006). It is easy to see how grass has selectively come to dominate in light of both human desire for a particular type of nature in cities that is accessible, open and easily managed, and then through inadvertent selection for example in the loss of animal engagement, and higher nutrient inputs. Wind-pollinated species, independent of mutualisms, small in size with shallow rooting systems and clonal reproductive capacity are traits that make an excellent urban species. Grass tends to have a high drought and heat tolerance, commonly associated with their $\mathrm{C} 4$ metabolic pathway which uses water efficiently, experiences limited water loss due to small leaf areas, and are independent of animal mutualisms. These grass species literally keep a low profile and are simultaneously actively selected for by people who have a suite of desires around open green space that are met by these low-growing, mat-forming, carpet-like plants (Larson et al. 2009). While a lush lawn requires a 
fair amount of watering, the expenditure of time and effort on lawn maintenance is testimony to the broad human affinity for this growth form and how it is categorically characteristic of modern cities (Zhou et al. 2009). The private garden spaces in the informal settlement of Vrygrond have the lowest plant cover. This can be attributed to less available income and time for planting as well possible social and safety considerations (Lubbe et al. 2010). These spaces, ecologically, emerge as particularly vulnerable spaces to environmental shock with low cover, little biological diversity, and low trait diversity. In their review of the role of biodiversity in ecosystem, Cardinale et al (2012) have as one of their consensus statements that higher biodiversity equates to higher ecosystem stability through time, and mechanistically we understand that diversity compensates for fluctuations in individual species populations and the functions they perform making them more resilient (Schewenius, McPhearson and Elmqvist 2014). Macro-scale climate change predictions for the City of Cape Town suggest increased temperatures and reduced rainfall and downscaled predictions confirm the increase in rainfall and show shifts towards either wetter or drier conditions (Taylor and Davies 2019). All models agree to significant climate change shifts and likely environmental perturbation. For example, drought will rapidly render these species-poor spaces as sources of mobile sand, flood waters will go unchecked, and ambient temperatures are likely to be higher (Alexandri and Jones 2008, Douglas et al. 2008). Given that we know functional diversity equates to resilience (Diaz and Cabido 2001, Cardinale et al. 2012, Schewenius, McPhearson and Elmqvist 2014) and that people are generally mentally and socially better-off with access to green space (Southon et al. 2018, Fuller et al. 2007), these are clearly sites that warrant attention with active landscape planning choices that see the inclusion of a diversity of species with the variability in traits that would make the landscapes more resilient to environmental perturbation and shocks. This 
research suggests that historically public planting choices have largely been made with maintenance as the informing factor, and while constrained circumstances will prevail, we argue that the additional factor of diversity and indigeneity could be readily added. To this end, the creation of a database of locally appropriate indigenous species with associated traits and horticultural requirements would be a useful next step. This could be used to inform city planting schemes as well as public campaigns run through nurseries.

While species richness in the conservation areas stands in stark contrast to private gardens and public green space diversity, this difference is not evident when considering functional traits. Trait richness in conservation areas is akin to that of wealthy private gardens. Generally, trait diversity is closely correlated with species diversity (Kraft et al. 2015). Local indigenous Fynbos flora has been described as having high functional similarity, in particular with a predominance of shrubby growth forms (Slingsby et al. 2014). Contemporary studies note the importance of functional diversity for system resilience (Diaz and Cabido 2001, Cardinale et al. 2012, Schewenius, McPhearson and Elmqvist 2014), and indeed this is a premise of this paper.

Any urban flora is a function of originally present native species, and subsequent introduced alien species (Williams et al. 2009) and this spread of indigenous and alien flora is evident across the gradient we studied in Cape Town. While alien species numbers are low in the conservation sites, those species that we found can be attributed to the neighbouring green spaces that are dominated by exotic plants, a well-known invasion process and problem for urban conservation spaces (Rebelo et al. 2011). As cities grow, previously rural conservation areas find themselves in or immediately adjacent to cities and the role of urban ecologies in informing or challenging biological conservation mandates warrants further attention (Borgstrom et al. 2013). This is particularly relevant to the City of Cape Town which is home to $18 \%$ of the national flora on 
$0.1 \%$ of the national area (Rebelo et al. 2011). The potential role of urban gardens as something of a supportive 'matrix' (Pauw and Louw 2012) is bought in to question where low rewarding species in public and private green space suggests these sites do not foster animals that might in turn support adjacent conservation sites. Similarly the dominant presence of alien flora, and the evident spread of this flora into urban conservation sites highlights the challenges of conservation in these human dominated landscapes where the selective forces and rationales at play are starkly divergent.

\subsection{Shifts across socio-economic gradients}

Within the urban matrix of private gardens, plant species richness follows an expected, globally (Pickett et al. 2011, Leong et al. 2018, Rigolon et al. 2018) and nationally (Lubbe et al. 2010) recognised, trend of declining richness across the socio-economic gradient described as the luxury effect (Hope et al. 2003, Leong et al. 2018). This private biodiversity, combined with the abundance of open green space in the richer, persistently white neighbourhoods, means these communities receive more of the recorded benefits associated with urban green space and biodiversity. Studies list numerous benefits of in situ ecosystem services, for example with research demonstrating improved mental and physical well-being in neighbourhoods with more green space (Gross and Lane 2007, Buchmann 2009, O’Farrell et al. 2012). The relatively low species richness of public spaces is consistent across the socio-economic gradient, presumably as a function of the management by a single entity in the form of the city's Parks and Recreation Department. Notable exceptions are the significantly low species richness in the public opens space of the wealthiest neighbourhood and the relatively higher richness of plant species in the

public open space of the informal settlement relative to adjacent private gardens. This first may be a function of the amount of green space in this neighbourhood and the possibly limited 
capacity to maintain this, or a desired and actively pursued air of neglect or 'wilderness' where Constantia is noted as a neighbourhood characterised by a semi-rural feel (Todeschini and Blackenberg, 2007). The second instance may be due to the unplanned nature of informal settlements which means the adjacent green spaces in this area may not fall to the care of the city and could be zoned for other purposes and these sites may remain unmanaged without the planting input evident in other neighbourhoods (Turok 2001).

The affluent neighbourhoods have also been settled for the longest. Poorer neighbourhoods on the Cape Flats, namely Retreat and Grassy Park, were settled following the rise of the Nationalist Party in 1948 and apartheid planning with forced removals of black and coloured citizens to live in the Cape Flats in the 1950s and 60s and these sites were typically bulldozed before construction, thus heavily altering soil composition and impacting natural vegetation. The informal settlement of Vrygrond is a possible exception where this land was never formally prepared by the city and thus it has simply been inhabited and possibly not bulldozed, potentially allowing the persistence of remnant patches of vegetation. Variable technologies and racistinformed histories of settlement with their legacies affect the persistence of remnant plant communities and would play out across this space and time continuum informing current plant communities. Traditional ecosystem assembly rules which inform natural plant communities, may still be at play in less managed public green spaces, but are wholly lost in highly managed private gardens (McGill et al. 2006). What emerges is a continuum of natural selective forces and traditional assembly rules operating in natural or unmanaged landscapes, with more passive urban selective forces informing urban conservation areas and poorer neighbourhoods and their adjacent public open space, to more active selective urban forces in wealthier neighbourhoods, especially in the private spaces of individual gardens. 
Selection for specific ecosystem services traits that give immediate benefit to the inhabitants is a common informant of garden plants, and this may differ across different socio-economic neighbourhoods, for example with selection for shade for cooling being more commonly recorded in poorer neighbourhoods (Larson et al. 2009). Similarly, drought tolerant or more water-wise species could be selected by poorer gardeners as a money-saving option where they require less water and less maintenance (Kendal et al. 2012). However, in the case of South Africa, where significant campaigns promoting water-wise gardening around the turn of the century emerged in response to drought and greater awareness of the use of water by plants, this could be an informing factor in garden choices in wealthier gardens. The relatively high presence of succulents in both the gardens of the wealthier neighbourhoods of Constantia and Tokai and the poorer informal settlement of Vrygrond could be a function of such active selective forces. Across the socioeconomic gradient the relationship between species richness and trait richness tends to hold (Kraft et al. 2015). Counts only tell so much of course, and the composite view of relative cover of growth forms and associated traits in each neighbourhood is more informative where system processes are sensitive to variations in composition of plant cover (Richardson et al. 1995).

The high alien flora at the wealthier end of the socio-economic gradient in Constantia and Tokai can be attributed to the planting of a diversity of exotic species in gardens as a function of access to greater disposable income (Hope et al. 2003, Pickett et al. 2011, Rigolon et al. 2018). In the informal settlements, the alien species recorded were typically those listed as problematic invaders and their presence here suggests biological circumstance of invasion rather than as a result of specific human choice and action. That said, the lack of municipal infrastructure and associated service provision in informal settlements which are for example frequently 
unconnected to city power supplies means that common invasive alien trees, such as Acacia cyclops, while not perhaps actively planted, are often fostered as a source of firewood (Petersen et al. 2012).

\subsection{The role of context and importance of trait diversity for resilience}

Diversity, in species and traits, is important for community stability and maintenance of ecosystem functionality (Cardinale et al. 2012, Mori et al. 2013). Traditional conservation strives for this end, serviced by a particular community and set of practitioners, but framed as linking community preservation with an often apparently tangential human need. The ecological communities constructed in our cities, where most people live, tend to reflect a very different set of ecological or social desires. The context, of course, is different, and no one would suggest the same set of rules apply. The ecological principles however still hold: diverse communities are more resilient to change and less vulnerable (Cardinale et al. 2012, Schewenius, McPhearson and Elmqvist 2014). As cities face change, or experience shocks which could be fast shocks like flooding or slower shocks for example, through racial separatist planning and social upheaval through forced removal and resettlement, some ecological systems will be more resilient to change and others stripped leaving local human communities more exposed to the full effect of environmental threats (Douglas et al. 2008, O'Farrell et al. 2012, Walker et al. 2012). Ecosystem functions may be lost more rapidly from species poor plant communities (Dobson et al. 2006, Cardinale et al. 2012) and functions in turn can be translated into ecosystem services which are then lost in turn (Flynn et al. 2009, Schewenius, McPhearson and Elmqvist 2014). Plant communities with less diversity would have less response diversity and may lose cover faster when faced with drought or disease, than a plant rich community (Elmqvist et al. 2003). The resulting bare open space and loss of associated ecosystem services could result, for example, in 
less urban cooling (Rogan et al. 2013), greater vulnerability to flooding (O'Farrell et al. 2012), or greater dust production (Berendse et al. 2015). Demonstrating these connections between diversity, functioning, and ecosystem service delivery, is still a growing area of research, and most examples are from rural landscapes (Dobson et al. 2006, Flynn et al. 2014, Pearse et al. 2018). Some urban examples do exist that demonstrate the link between diversity and ecosystem services. For example, Riley, Herms, and Gardiner (2018) show that vacant city lots with higher tree diversity deliver greater ecosystem services. O'Farrell et al. (2012), provide a local example from the City of Cape Town, where they demonstrate the loss of indigenous plant cover results in an associated loss in the delivery of in situ ecosystem services. Their work shows the loss of flood mitigation services in riparian areas and the loss of coastal storm surge mitigation. There is scope for further work in making explicit the links between diversity, function and ecosystem services in the urban context.

Several studies of plant functional traits make a clear case for the critical role of context in informing any urban flora (Hahs 2009, Duncan et al. 2011) where regional climate, original flora, history of development all vary between urban settlements and prove critical in informing local floras. So while generalities are sought, and indeed in numerous cases certain traits are typically favoured or lost in the urban settlement process, the less immediately apparent role of local factors is important. Evident in this case is the role of apartheid-planning. Increasingly ecosystem histories, contemporary ecosystem properties, likely associated ecosystem services and environmental justice, are recognised as linked (Goodness et al. 2016, Lavorel et al. 2011). There is a call for planners, with the support of ecologists and ecological knowledge, to engage with sustainability issues and to direct development towards securing the ecosystems that produce important resources and underpin ecosystem services (Ahern 2013, Schewenius, 
McPhearson and Elmqvist 2014). Ahern (2013) lists a number of critical factors for

consideration in guiding planners in working towards more ecologically resilient landscapes and many of these resonate with the findings of this study. He notes the need to secure biodiversity and to establish ecological connectivity. He calls for the planning and design of multifunctional landscapes to this end, which is in accord with the case of the City of Cape Town where there are both social development and conservation imperatives (Turok 2001, Rebelo et al. 2011) and multifunctional landscapes should be planned to meet both biodiversity conservation and social needs.

\section{CONCLUSION}

There is a marked shift between the rural and urban plant communities in the City of Cape Town, rendering them completely different communities with little structural and functional affinity. This poses questions for the future of small conservation 'islands', used here as a proxy for a rural equivalent, in an urban setting. Urban landscapes are grass-dominated, akin to grasslands, with little structural and functional diversity when compared to the rural counterpart. There are

missed opportunities for greater, and better informed biological diversity, to meet both social and conservation ends, particularly in open public green spaces that can be more collectively informed and speak to local social and conservation needs. Planting in public open space should be far more ecologically-informed, with a view to better connectivity to counter the evident disconnections between patches demonstrated here and greater indigenous diversity towards meeting conservation needs (Rebelo et al. 2011).

This study found a significant ecological gradient of reduced biodiversity, traits, and in turn functionality, across a socio-economic gradient in the City of Cape Town. Wealthier and racially 
predominantly white communities in Cape Town benefit from more private green space, more public green space, and a greater ecological diversity. Poorer, and majority black and coloured, communities have limited green space on all fronts, and what is there, might be described as ecologically 'poor' where plant cover, species richness and trait richness are all lower than wealthier neighbourhoods. A depauperate ecology, or what might be termed an ecological poverty, mirrors historical apartheid planning that is resistant to change. Recent linkages between ecosystem properties, diversity and functionality and associated ecosystem services and vulnerabilities suggests a significant environmental injustice persists that warrants attention. While campaigns to promote private garden planting to better sustain a more coherent city-wide ecological system would be useful, private wealth might constrain this in certain neighbourhoods, and here there needs to be an even greater effort on the part of those departments who are responsible for public planting to ensure these shared spaces are reformed to more species rich and ideally locally indigenous plant communities. 


\section{REFERENCE LIST}

1. Alexandri, E., \& Jones, P. (2008). Temperature decreases in an urban canyon due to green walls and green roofs in diverse climates. Building and Environment, 43(4), 480-493.

2. Ahern, J. (2013). Urban landscape sustainability and resilience: the promise and challenges of integrating ecology with urban planning and design. Landscape ecology, 28(6), 1203 1212.

3. Allsopp, N., Anderson, P. M. L., Holmes, P. M., Melin, A., \& O’Farrell, P. J. (2014). People, the Cape Floristic Region, and sustainability (pp. 337-360). In N. Allsopp, J. F. Colville, G. A. Verboom, \& R. M. Cowling, (Eds.), Fynbos: Ecology, Evolution and Conservation of a Megadiverse Region. Oxford - Oxford.

4. Anderson, P.M., Okereke, C., Rudd, A. \& Parnell, S. (2013). Regional assessment of Africa (pp.453 - 459). In T. Elmqvist, M. Fragkias, J. Goodness, B. Guneralp, P.J. Morcotullio, R. I. McDonald, S. Parnell, M. Schewenius, M. Sendstad, K.C. Seto, \& C. Wilkinson (Eds.), Urbanization, biodiversity and ecosystem services: Challenges and opportunities. Springer - Netherlands.

5. Anderson, P. \& O'Farrell, P. (2012). An ecological view of the history of the City of Cape Town. Ecology and Society, 17(3).

6. Berendse, F., van Ruijven, J., Jongejans, E. \& Keesstra, S. (2015). Loss of plant species diversity reduces soil erosion resistance. Ecosystems, 18(5), 881-888.

7. Bivand, R., \& Piras, G. (2015). Comparing implementations of estimation methods for spatial econometrics. Journal of Statistical Software, 63(18), 1-36.

8. Borcard D., Gillet, F., \& Legendre, P. (2011). Numerical Ecology with R. Springer, New York, Dordrechet, London, Heidelberg.

9. Borgström, S., Lindborg, R., \& Elmqvist, T. (2013). Nature conservation for what? Analyses of urban and rural nature reserves in southern Sweden 1909-2006. Landscape and Urban Planning, 117, 66-80.

10. Buchmann, C. (2009). Cuban home gardens and their role in social-ecological resilience. Human Ecology, 37(6),705. 
11. Cardinale, B.J., Duffy, J.E., Gonzalez, A., Hooper, D.U., Perrings, C., Venail, P., Narwani, A., Mace, G.M., Tilman, D., Wardle, D.A. \& Kinzig, A.P. (2012). Biodiversity loss and its impact on humanity. Nature, 486(7401), 59.

12. Díaz, S. \& Cabido, M. (2001). Vive la difference: plant functional diversity matters to ecosystem processes. Trends in Ecology and Evolution, 16(11), 646-655.

13. Dobson, A., Lodge, D., Alder, J., Cumming, G.S., Keymer, J., McGlade, J., Mooney, H., Rusak, J.A., Sala, O., Wolters, V. \& Wall, D. (2006). Habitat loss, trophic collapse, and the decline of ecosystem services. Ecology, 87(8), 915-1924.

14. Douglas, I., Alam, K., Maghenda, M., Mcdonnell, Y., McLean, L., \& Campbell, J. (2008). Unjust waters: climate change, flooding and the urban poor in Africa. Environment and Urbanization, 20(1),187-205.

15. Duncan, R.P., Clemants, S.E., Corlett, R. T., Hahs, A. K. McCarthy, M.A., McDonnell, M.J., Schwartz, M. J., Thompson, K., Vesk, P.A., \& Williams, N.S. (2011). Plant traits and extinction in urban areas: a meta-analysis of 11 cities. Global Ecology and Biogeography, 20(4), 509-519.

16. Elmqvist, T., Folke, C., Nyström, M., Peterson, G., Bengtsson, J., Walker, B. \& Norberg, J., 2003. Response diversity, ecosystem change, and resilience. Frontiers in Ecology and the Environment, 1(9) 488-494.

17. Faeth, S.H., Bang, C., \& Saari, S. (2011). Urban biodiversity: patterns and mechanisms. Annals of the New York Academy of Sciences, 1223, 69-81.

18. Flynn, D.F., Gogol-Prokurat, M., Nogeire, T., Molinari, N., Richers, B.T., Lin, B.B., Simpson, N., Mayfield, M.M. \& DeClerck, F. (2009). Loss of functional diversity under land use intensification across multiple taxa. Ecology letters, 12(1),22-33.

19. Fragkias, M., Güneralp, B., Seto, K.C., \& Goodness, J. (2013). A synthesis of global urbanization projections (pp.409 - 435). In T. Elmqvist, M. Fragkias, J. Goodness, B. Guneralp, P.J. Morcotullio, R. I. McDonald, S. Parnell, M. Schewenius, M. Sendstad, K.C. Seto, \& C. Wilkinson (Eds.), Urbanization, biodiversity and ecosystem services: Challenges and opportunities. Springer - Netherlands.

20. Fuller, R.A., Irvine, K.N., Devine-Wright, P., Warren, P.H., \& Gaston, K. J. (2007). Psychological benefits of greenspace increase with biodiversity. Biology Letters, 3(4), 390394. 
21. Funk, J.L., Larson, J.E., Ames, G.M., Butterfield, B.J., Cavender-Bares, J., Firn, J., Laughlin, D.C., Sutton-Grier, A.E., Williams, L. \& Wright, J. (2017). Revisiting the H oly G rail: using plant functional traits to understand ecological processes. Biological Reviews, 92(2), 1156-1173.

22. Funk, J.L., Cleland, E.E., Suding, K.N. \& Zavaleta, E.S. (2008). Restoration through reassembly: plant traits and invasion resistance. Trends in ecology \& evolution, 23(12), 695703.

23. Goddard, M.A., Dougill, A.J., \& Benton, T.G. (2010). Scaling up from gardens: biodiversity conservation in urban environments. Trends in Ecology \& Evolution, 25(2), 90-98.

24. Gonzalez-Garcia, A., Belliure, J., Gómez-Sal, A., \& Dávila P. (2009). The role of urban greenspaces in fauna conservation: the case of the iguana Ctenosaura similis in the 'patios' of León city, Nicaragua. Biodiversity and conservation, 18(7), 1909.

25. Goodness, J., Andersson, E., Anderson, P. M., \& Elmqvist, T. (2016). Exploring the links between functional traits and cultural ecosystem services to enhance urban ecosystem management. Ecological Indicators, 70, 597-605.

26. Goodness, J., \& Anderson, P.M. (2013). Local assessment of Cape Town: navigating the management complexities of urbanization, biodiversity, and ecosystem services in the Cape Floristic Region (pp.461-484). In T. Elmqvist, M. Fragkias, J. Goodness, B. Guneralp, P.J. Morcotullio, R. I. McDonald, S. Parnell, M. Schewenius, M. Sendstad, K.C. Seto, \& C. Wilkinson (Eds.), Urbanization, biodiversity and ecosystem services: Challenges and opportunities. Springer - Netherlands.

27. Graham, S., \& Marvin, S. (2001). Splintering Urbanism. Networked infrastructures, technological mobilities and the urban condition. Routledge - New York.

28. Gross, H., \& Lane, N. (2007). Landscapes of the lifespan: Exploring accounts of own gardens and gardening. Journal of Environmental Psychology, 27(3), 225-241.

29. Hahs, A.K., McDonnell, M.J., McCarthy, M.A., Vesk, P.A., Corlett, R.T., Norton, B.A., Clemants, S.E., Duncan, R.P., Thompson, K., Schwartz, M.W., \& Williams, N.S. (2009). A global synthesis of plant extinction rates in urban areas. Ecology Letters, 12(11), 1165-1173. 30. Hope, D., Gries, C., Zhu, W., Fagan, W.F., Redman, C.L., Grimm, N.B., Nelson, A.L., Martin, C. \& Kinzig, A. (2003). Socioeconomics drive urban plant diversity. Proceedings of the national academy of sciences, 100(15), 8788-8792. 
31. Jepson Flora Project. (2016). Jepson eFlora, http://ucjeps.berkeley.edu/eflora/ [accessed on Aug 24, 2016].

32. Kattge, J., Diaz, S., Lavorel, S., Prentice, I.C., Leadley, P., Bönisch, G., Garnier, E., Westoby, M., Reich, P.B., Wright, I.J., \& Cornelissen J.H.C. (2011). TRY-a global database of plant traits. Global Change Biology, 17 (9), 2905-2935.

33. Kendal, D., Williams, N.S. \& Williams, K.J. (2012). Drivers of diversity and tree cover in gardens, parks and streetscapes in an Australian city. Urban forestry \& urban greening, 11(3), pp.257-265.

34. Knapp, S., Dinsmore, L., Fissore, C., Hobbie, S.E., Jakobsdottir, I., Kattge, J., King, J., Klotz, S., McFadden, J.P., \& Cavender-Bares, J. (2012). Phylogenetic and functional characteristics of household yard floras and their changes along an urbanization gradient. Ecology, 9 (8), 83-98.

35. Kraft, N.J., Godoy, O., \& Levine, J.M. (2015). Plant functional traits and the multidimensional nature of species coexistence. Proceedings of the National Academy of Sciences, 112(3), 797-802.

36. Kremen, C. (2005.) Managing ecosystem services: what do we need to know about their ecology?. Ecology letters, 8(5), 468-479.

37. Kuruneri-Chitepo, C., \& Shackleton, C. M. (2011). The distribution, abundance and composition of street trees in selected towns of the Eastern Cape, South Africa. Urban Forestry \& Urban Greening, 10(3), 247-254.

38. Larson, K.L., Casagrande, D., Harlan, S.L., \& Yabiku, S. T. (2009). Residents' yard choices and rationales in a desert city: social priorities, ecological impacts, and decision trade-offs. Environmental Management, 44(5), 921.

39. Lavorel, S., Grigulis, K., Lamarque, P., Colace, M. P., Garden, D., Girel, J., Pellet,G., \& Douzet, R. (2011). Using plant functional traits to understand the landscape distribution of multiple ecosystem services. Journal of Ecology, 99(1),135-147.

40. Leong, M., Dunn, R.R. \& Trautwein, M.D. (2018). Biodiversity and socioeconomics in the city: a review of the luxury effect. Biology letters, 14(5), p.20180082.

41. Lowery, A. (2016). Racial and Socioeconomic Disparities in Distribution of Green Space in Cape Town, South Africa. Unpublished student thesis. University of Cape Town. 
42. Lubbe, C.S., Siebert, S. J. \& Cilliers S.S. (2010). Political legacy of South Africa affects the plant diversity patterns of urban domestic gardens along a socio-economic gradient. Scientific Research and Essays, 5(19), 2900-2910.

43. McDonnell, M.J., \& Hahs, A.K. (2013). The future of urban biodiversity research: moving beyond the 'low-hanging fruit'. Urban Ecosystems, 16(3), 397-409.

44. McGill, B.J., Enquist, B.J., Weiher, E., \& Westoby, N. (2006). Rebuilding community ecology from functional traits. Trends in Ecology and Evolution, 21(4), 178-185.

45. McPhearson, T., Andersson, E., Elmqvist, T. \& Frantzeskaki, N. (2015). Resilience of and through urban ecosystem services. Ecosystem Services, 12,152-156.

46. Mieklejohn, C. \& le Roux, S. (2008). A National Overview of Spatial Trends and Settlement Characteristics: Annexure A, Population Characteristics and Location. CSIR, Pretoria.

47. Mori, A.S., Furukawa, T., \& Sasaki, T. (2013). Response diversity determines the resilience of ecosystems to environmental change. Biological Reviews, 88(2), 349-364.

48. O'Farrell, P.J., Anderson, P. M., Le Maitre, D.C., \& Holmes, P.M. (2012). Insights and opportunities offered by a rapid ecosystem service assessment in promoting a conservation agenda in an urban biodiversity hotspot. Ecology and Society, 17(3), 27.

49. Oksanen, J., Blanchet, F. G., Kindt, R., Legendre, P., Minchin, P. R., \& O'Hara, R. B. (2013). Vegan: Community ecology package r package version 2. 0-10. http://CRAN.Rproject.org/package.

50. Pearse, W.D., Cavender-Bares, J., Hobbie, S.E., Avolio, M.L., Bettez, N., Roy Chowdhury, R., Darling, L.E., Groffman, P.M., Grove, J.M., Hall, S.J. \& Heffernan, J.B. (2018). Homogenization of plant diversity, composition, and structure in North American urban yards. Ecosphere, 9(2), p.e02105.

51. Pauw, A., \& Louw, K. (2012). Urbanization drives a reduction in functional diversity in a guild of nectar-feeding birds. Ecology and Society, 17(2), 27.

52. Pauw, A. (2007). Collapse of a pollination web in small conservation areas. Ecology, 88(7), 1759-1769.

53. Peres-Neto P. R., Legendre, P., Dray, S., \& Borcard, D. (2006). Variation partitioning of species data matrices: estimation and comparison of fractions. Ecology, 87(10), 2614-2625. 
54. Petersen, L., Moll, E., Collins, R. \& Hockings, M. (2012). Development of a compendium of local, wild-harvested species used in the informal economy trade, Cape Town, South Africa. Ecology and Society, 17(2).

55. Pickett, S.T., Cadenasso, M. L., Grove, J.M., Boone, C.G., Groffman, P.M., Irwin, E., Kaushal, S.S., Marshall, V., McGrath, B.P., Nilon, C. H., \& Pouyat, R.V. (2011). Urban ecological systems: Scientific foundations and a decade of progress. Journal of Environmental Management, 92(3), 331-362.

56. Rebelo, A.G., Boucher, C., Helme, N., Mucina, L. \& Rutherford, M, C. (2006). Fynbos Biome (pp. 52 - 219). In L. Mucina, L. \& M.C. Rutherford (Eds). The Vegetation of South Africa, Lesotho and Swaziland. Pretoria: South African National Biodiversity Institute.

57. Rebelo, A.G., Holmes, P.M., Dorse, C., \& Wood, J. (2011). Impacts of urbanization in a biodiversity hotspot: conservation challenges in Metropolitan Cape Town. South African Journal of Botany, 77(1), 20-35.

58. Richardson, D.M., Cowling, R. M., Bond, W. J., Stock, W. D., \& Davis, G.W. (1995). Links between biodiversity and ecosystem function in the Cape Floristic Region (pp. 285 - 333). In G. W. Davis \& D. M. Richardson (Eds.), Mediterranean-Type Ecosystems. BerlinSpringer.

59. Rigolon, A., Browning, M., Lee, K. \& Shin, S. (2018). Access to urban green space in cities of the global south: A systematic literature review. Urban Science, 2(3), 67.

60. Riley, C.B., Herms, D.A. and Gardiner, M.M. (2018). Exotic trees contribute to urban forest diversity and ecosystem services in inner-city Cleveland, OH. Urban Forestry \& Urban Greening, 29, 367-376.

61. Robbins, P., \& Sharp, J. (2006). Turfgrass subjects: the political economy of urban monoculture (pp. 110 - 128). In E. Swingedouw, N. Heynen \& M. Kaika, (Eds.), In the nature of cities: Urban political ecology and the politics of urban metabolism. LondonRoutledge.

62. Rogan, J., Ziemer, M., Martin, D., Ratick, S., Cuba, N. \& DeLauer, V. (2013). The impact of tree cover loss on land surface temperature: A case study of central Massachusetts using Landsat Thematic Mapper thermal data. Applied Geography, 45, 49-57. 
63. Schewenius, M., McPhearson, T. \& Elmqvist, T. (2014). Opportunities for increasing resilience and sustainability of urban social-ecological systems: insights from the URBES and the cities and biodiversity outlook projects. Ambio, 43(4), 434-444.

64. Seto, K.C., Parnell, S., \& Elmqvist, T. (2013). A global outlook on urbanization (pp. 1 12). In T. Elmqvist, M. Fragkias, J. Goodness, B. Guneralp, P.J. Morcotullio, R. I. McDonald, S. Parnell, M. Schewenius, M. Sendstad, K.C. Seto, \& C. Wilkinson (Eds.), Urbanization, biodiversity and ecosystem services: Challenges and opportunities. Springer - Netherlands.

65. Slingsby, J.A., Ackerly, D.D., Latimer, A. M., Linder, P. H., \& Pauw, A. (2014). The assembly and function of Cape plant communities in a changing world (pp. 200-223). In N. Allsopp, J. F. Colville, G. A. Verboom, \& R. M. Cowling, (Eds.), Fynbos: Ecology, Evolution and Conservation of a Megadiverse Region. Oxford - Oxford.

66. Smith, R.M., Warren, P. H., Thompson, K., \& Gaston, K. J. (2005). Urban domestic gardens (VI): environmental correlates of invertebrate species richness (pp. 75 - 98). In D. L. Hawksworth, \& A. T. Bull, (Eds.), Human exploitation and biodiversity conservation. Netherlands - Springer.

67. Southon, G.E., Jorgensen, A., Dunnett, N., Hoyle, H. \& Evans, K.L. (2018). Perceived species-richness in urban green spaces: Cues, accuracy and well-being impacts. Landscape and Urban Planning, 172,1-10.

68. South African National Biodiversity Institute. 2008. PlantZAfrica. Available at: http://www.plantzafrica.com/. [accessed on Aug 24, 2016].

69. Taylor, A. \& Davies, H. (2019). An overview of climate change and urban development in Cape Town (pp 40 - 61). In D. Scot, H. Davies \& M. New (Eds.), Mainstreaming Climate Change In Urban Development. UCT Press - Cape Town.

70. Thompson, K., \& McCarthy, M. A. (2008). Traits of British alien and native urban plants. Journal of Ecology, 96(5), 853-859.

71. Todeschini, F., \& Blackenberg, J. (2007). Tangible Heritage Resources in the Constantia Tokai Valley Towards a Conservation Management Plan for the Cape Winelands Cultural Landscape Phase 1 Report Volume. [Online]. Accessed: http://www.constantiapoa.co.za/. [12 June 2017]. 
72. Tomimatsu, H., Sasaki, T., Kurokawa, H., Bridle, J.R., Fontaine, C., Kitano, J., Stouffer, D.B., Vellend, M., Bezemer, T.M., Fukami, T. \& Hadly, E.A. (2013). Sustaining ecosystem functions in a changing world: a call for an integrated approach. Journal of Applied Ecology, 50(5), pp.1124-1130

73. Turok, I. (2001). Persistent polarisation post-apartheid? Progress towards urban integration in Cape Town. Urban studies, 38(13), 2349-2377.

74. USDA, NRCS. (2016). The PLANTS Database (http://plants.usda.gov, 22 August 2016).

75. Walker, B., Carpenter, S., Rockstrom, J., Crépin, A.S. \& Peterson, G. (2012). Drivers," slow" variables," fast" variables, shocks, and resilience. Ecology and Society, 17(3).

76. Williams, N. S., Schwartz, M. W., Vesk, P. A., McCarthy, M. A., Hahs, A. K., Clemants, S. E., \& McDonnell, M. J. (2009). A conceptual framework for predicting the effects of urban environments on floras. Journal of Ecology, 97(1), 4-9.

77. Zhou, W., Troy, A., Grove, M. J., \& Jenkins, J. C. (2009). Can money buy green? Demographic and socioeconomic predictors of lawn-care expenditures and lawn greenness in urban residential areas. Society and Natural Resources, 22(8), 744-760. 
Table 1. Socio-economic and demographic data for the different neighbourhoods sampled across the gradient. Percentage annual earnings by neighbourhood are given as the percentage earning in the top and bottom end categories and serve as indicators of the respective wealth of these neighbourhoods. Green space per person follows Lowery (2016) who presents designated public greenspace per capita in the neighbourhoods.

\begin{tabular}{lllllll}
\hline Neighbourhood & $\begin{array}{l}\text { Black } \\
\text { African }\end{array}$ & Coloured & White & $\begin{array}{l}\text { \% earning } \\
<\mathbf{R ~ 1 0 ~ 0 0 0}\end{array}$ & $\begin{array}{l}\text { \% earning } \\
>\text { R 2500 000 }\end{array}$ & $\begin{array}{l}\text { Amount of green } \\
\text { space per person } \\
\left(\mathbf{m}^{2}\right)\end{array}$ \\
\hline Constantia / Tokai & 10.6 & 24.0 & 62.7 & 6 & 10 & 1561.0 \\
\hline Bergvliet & 5.0 & 6.2 & 86.3 & 7 & 6 & 295.4 \\
\hline Retreat & 9.1 & 84.0 & 3.1 & 12 & 0 & 33.5 \\
Grassy Park & 7.7 & 88.0 & 0.3 & 13 & 0 & 11.1 \\
\hline Vrygrond & 60.1 & 30.8 & 0.1 & 35 & 0 & 21.0 \\
\hline
\end{tabular}


Table 2. Average species, traits numbers, and cover $( \pm$ STD) for private gardens and public green space by neighbourhood, and for conservation areas for $5 \mathrm{~m}^{2}$ plots. Post hoc differences presented are according to column headings and only for the three primary land use categories. Species numbers differ significantly between the conservation areas and both the public green space and private gardens $(p<0.0001$ in both cases). Trait numbers differ significantly between public green space and conservation areas only ( $\mathrm{p}<$ 0.01). Cover values differ significantly between the conservation areas and both the public green space and private gardens $(\mathrm{p}<0.0001$ in both cases). Significant post-hoc differences are marked between neighbourhoods and are all significant at the $\mathrm{p}<0.01$ level. Across neighbourhoods species numbers and traits numbers did not differ between public and private land use. Across private gardens species numbers and traits numbers differed significantly between Bergvliet, Retreat and Constantia/ Tokai at the $\mathrm{p}<0.0001$ level.

\begin{tabular}{|c|c|c|c|c|}
\hline Neighborhood & Management & $\begin{array}{l}\text { Average } \\
\text { number of } \\
\text { species } \\
( \pm \text { STD })\end{array}$ & $\begin{array}{l}\text { Average } \\
\text { number of } \\
\text { traits }( \pm \text { STD })\end{array}$ & $\begin{array}{l}\text { Average cover } \\
(\%)( \pm \text { STD })\end{array}$ \\
\hline \multirow{2}{*}{ Constantia / Tokai } & Private & $6.8(2.9)$ & $29.2(4.5)$ & $84.3(24.6)$ \\
\hline & Public & $3.9(2.0)$ & $23.9(5.1)$ & $94.4(21.8)$ \\
\hline \multirow[t]{2}{*}{ Bergvliet } & Private & $5.0(1.5)$ & $27.5(3.2)$ & $87.4(21.6)$ \\
\hline & Public & $5.1(1.8)$ & $26.5(5.3)$ & $69.6(32.9)$ \\
\hline \multirow{2}{*}{ Retreat } & Private & $6.1(2.4)$ & $27.9(5.6)$ & $99.7(24.7)$ \\
\hline & Public & $5.3(2.7)$ & $25.6(5.6)$ & $75.3(26.5)$ \\
\hline \multirow[t]{2}{*}{ Grassy Park } & Private & $4.7(1.4)$ & $25.8(3.0)$ & $81.7(24.9)$ \\
\hline & Public & $5.7(2.9)$ & $26.1(5.6)$ & $97.9(17.2)$ \\
\hline \multirow[t]{2}{*}{ Vrygrond } & Private & $2.3(0.8)$ & $21.4(5.1)$ & $28.6(26.2)^{b}$ \\
\hline & Public & $4.0(0.7)$ & $25.8(2.2)$ & $75.0(28.8)$ \\
\hline All private sites & & $5.3(2.4)^{\mathrm{a}}$ & $26.8(4.9)^{a b}$ & $79.8(32.2)^{\mathrm{a}}$ \\
\hline All public sites & & $4.9(2.4)^{\mathrm{a}}$ & $25.6(5.1)^{a}$ & $82.5(32.2)^{\mathrm{a}}$ \\
\hline All conservation areas & & $8.5(3.1)^{b}$ & $29.3(4.2)^{b}$ & $99.8(18.2) b$ \\
\hline
\end{tabular}




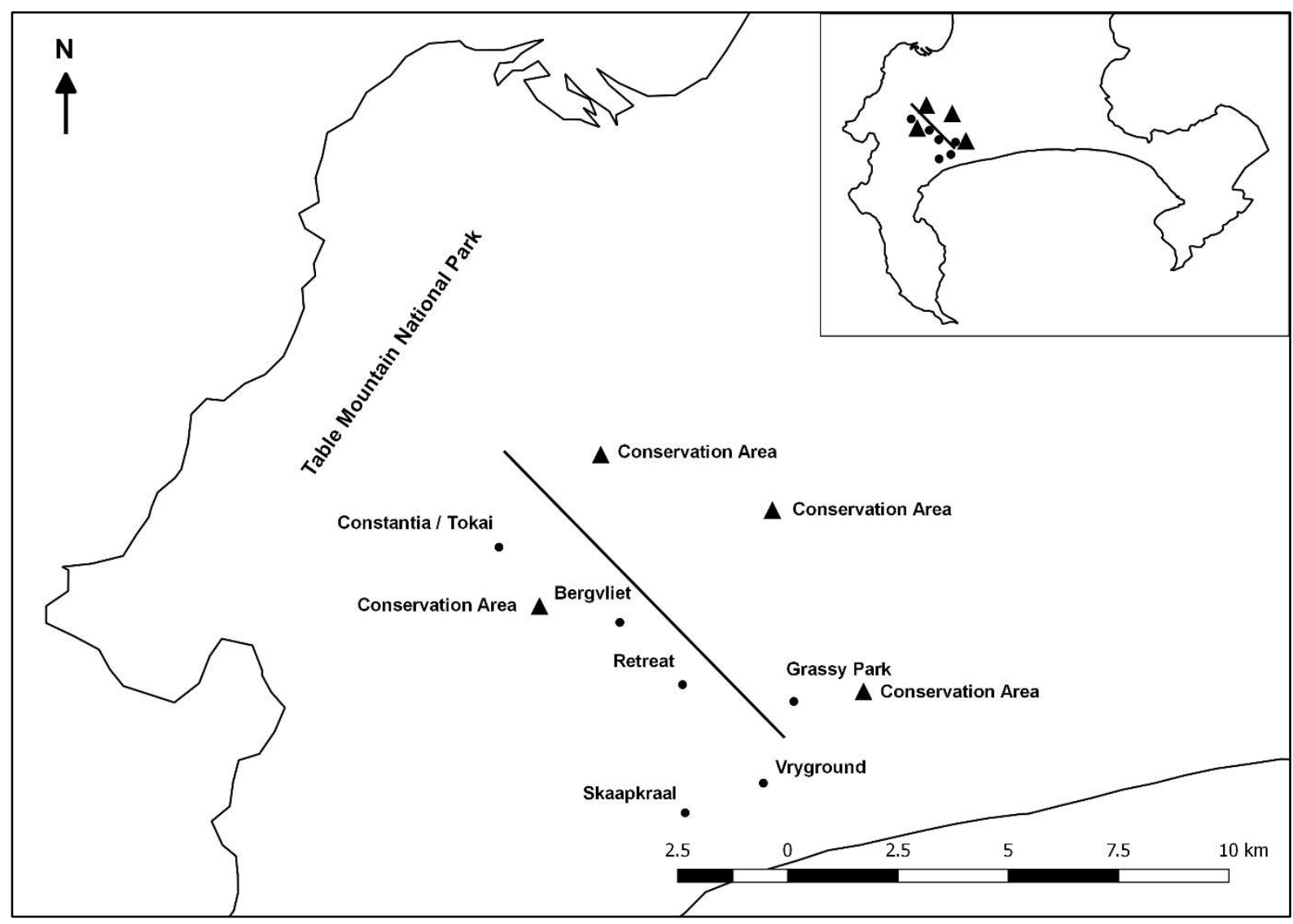

Figure 1. Map of the study site showing the neighbourhoods and conservation areas sampled across the socio-economic gradient within the City of Cape Town 


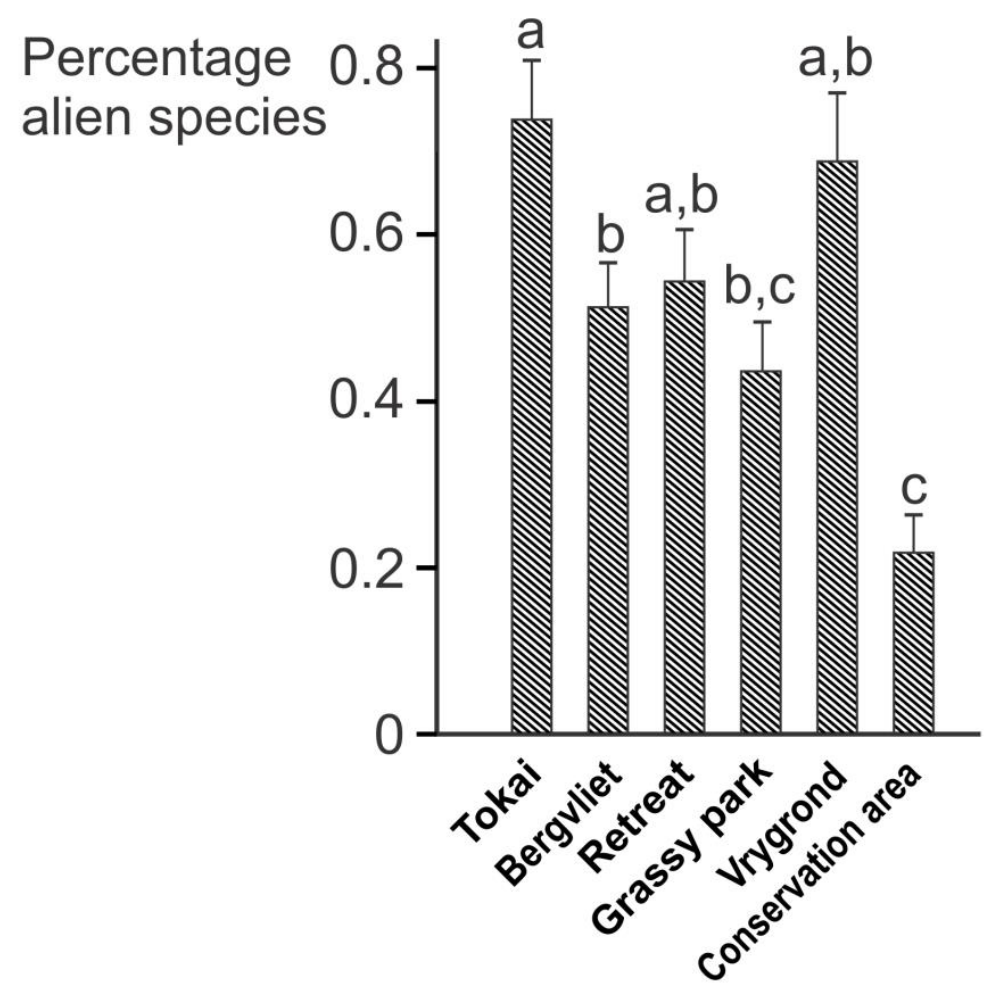

Figure 2. The percentage contribution of alien species to the garden and conservation flora of sites sampled. Grouping letters show the result of a multiple Wilcoxon-Mann-Whitney test with a Holm correction ( 0.95 confidence level) performed after a Kruskal-Wallis Rank Sum Test (Kruskal-Wallis X2 = $32.476 ; \mathrm{df}=5 ; \mathrm{P}<0.001)$. 


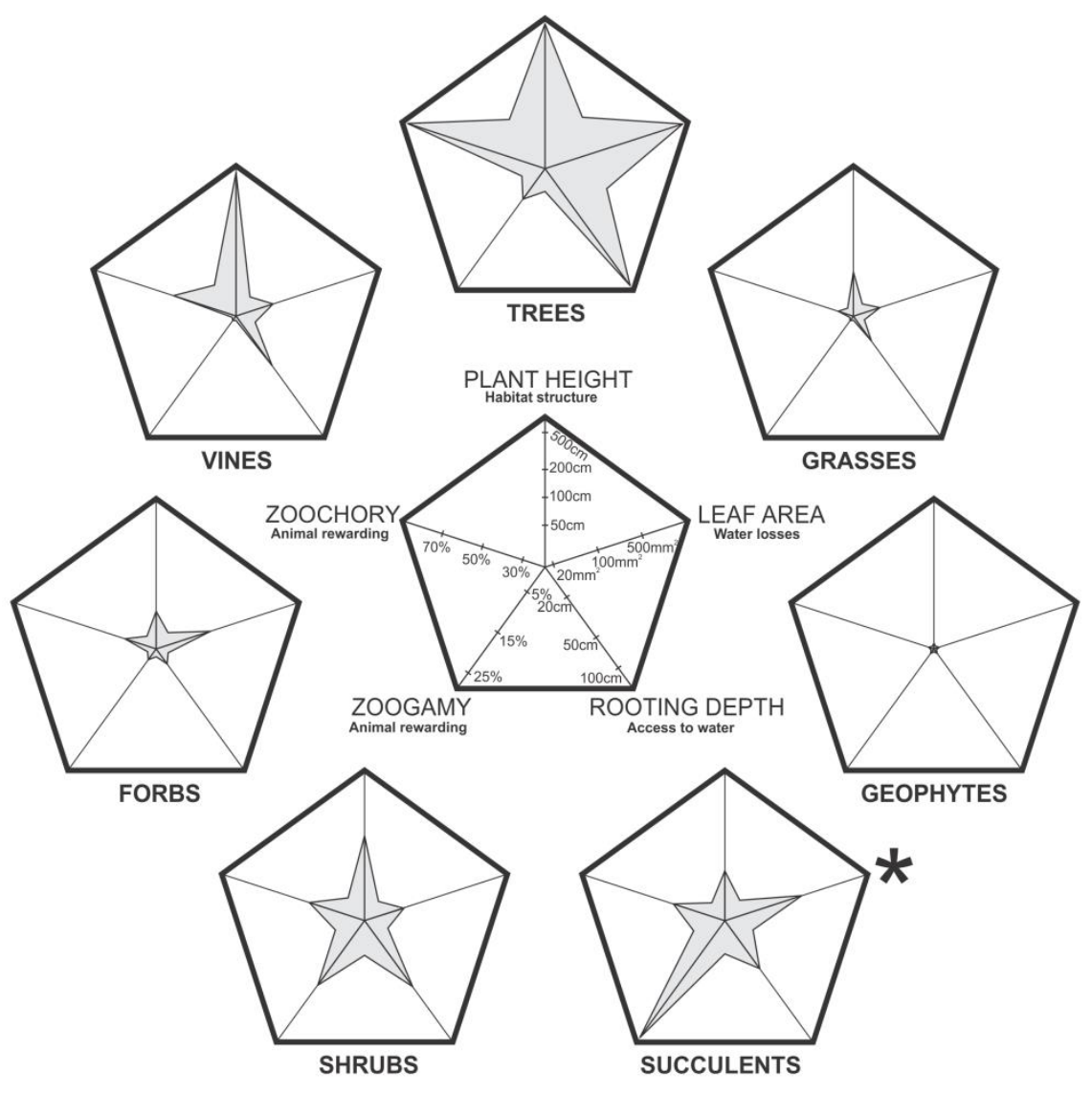

Figure 3. Radar diagrams of the associated dominant traits for the different growth forms under consideration shows the trait contribution of these growth forms. 


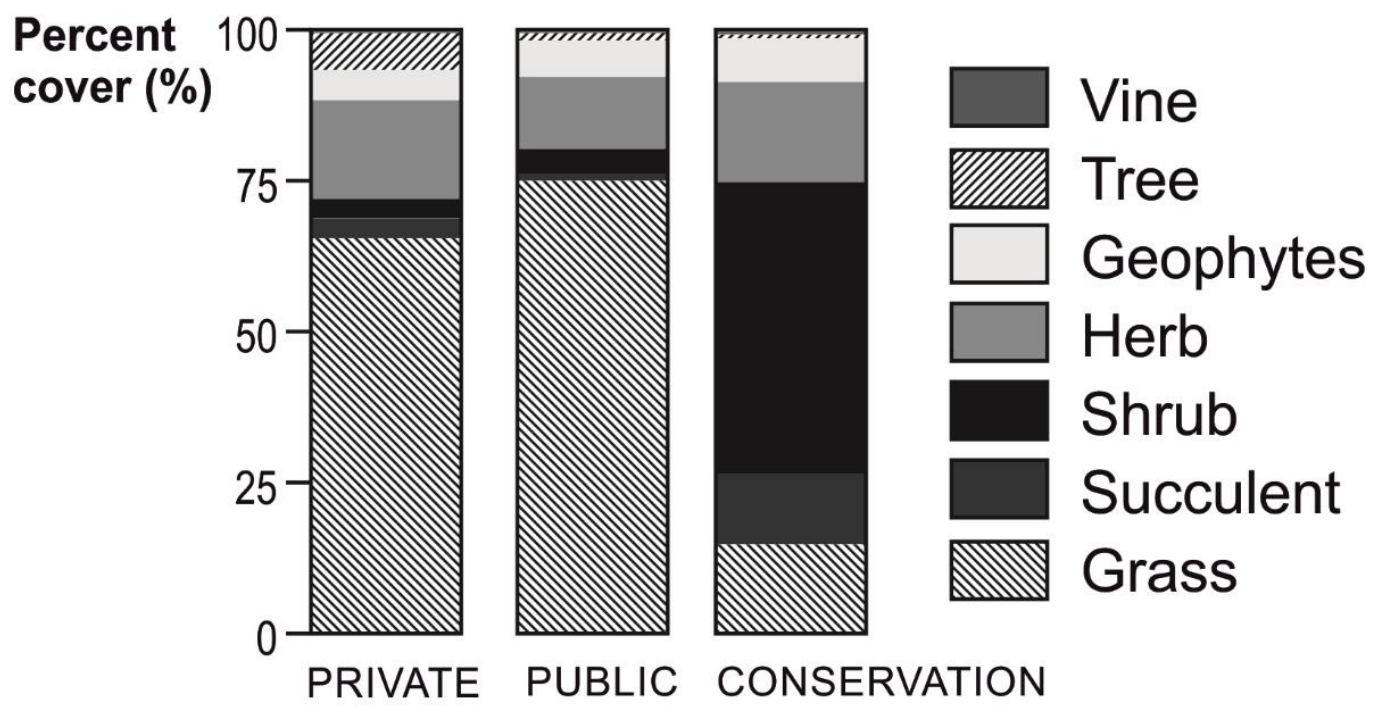

Figure 4. Percentage growth forms across the rural-urban gradient, with consideration of public and private green space (maximum height on each bar is 100\%). 


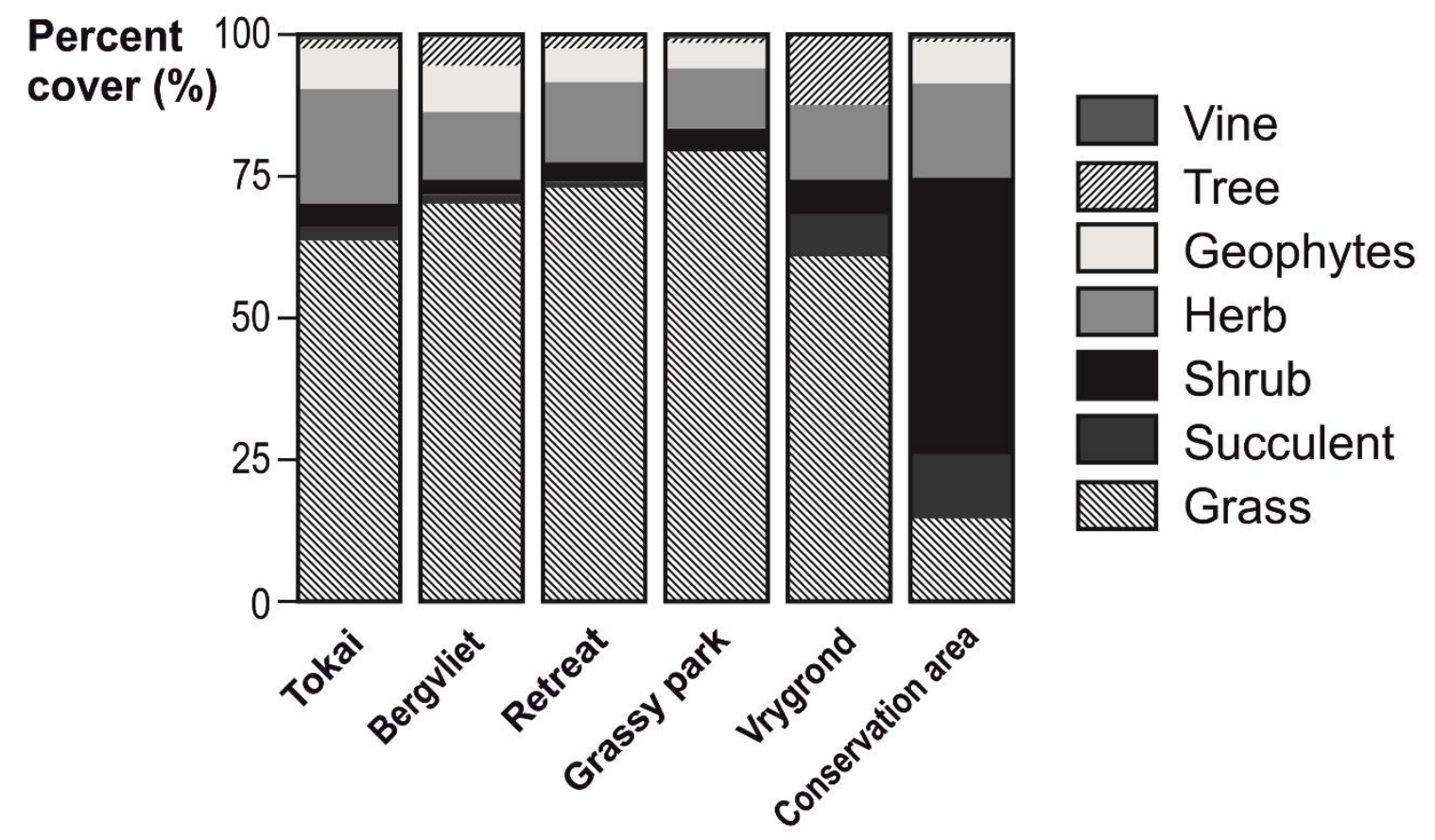

Figure 5. Relative percentage cover of growth form diversity across the socio-economic (wealthier to poorer neighbourhoods from left to right) gradient in private gardens, contrasted to the rural state in the form of the conservation areas (maximum height on each bar is 100\%). 
a. Seed dispersal

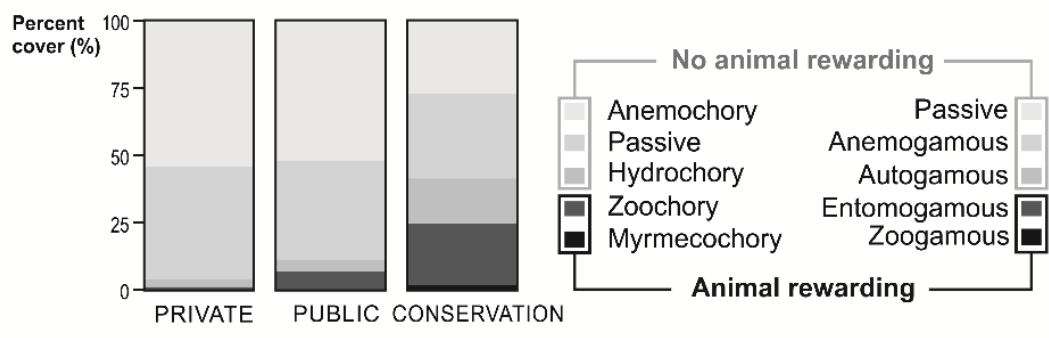

b. Pollination

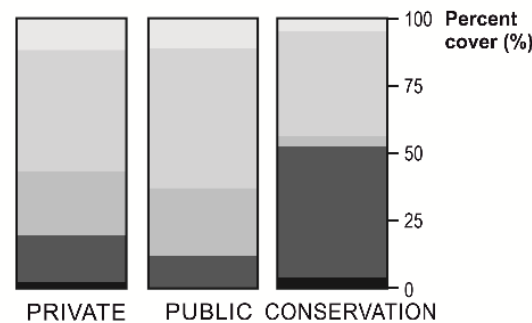

Figure 6. Relative percentage of growth form cover according to seed dispersal and pollination modes. A close examination of the role of animals as selective forces in cities shows the loss of animal-related traits. 


\section{DISTRIBUTION OF LIFE FORMS}

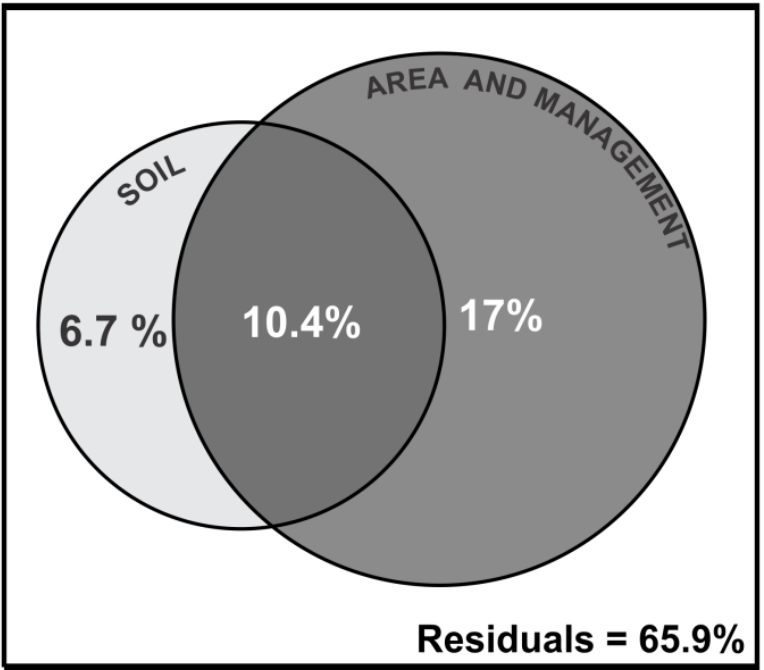

Figure 7. Venn diagrams of the variation partitioning of the life form distribution explained by two data sets corresponding to soil versus socio-economic factors. Fractions corresponding to unique effects have been tested by partial CCA and are both significant $(\mathrm{P}<0.001)$. Residuals correspond to the fraction not explained by the overall model. Values reported are adjusted coefficients of determination. Circle sizes are proportional to the corresponding $\mathrm{R}^{2}$ adj. Details of the results are presented in tab. S3. 